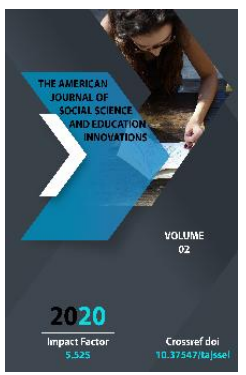

\title{
Investigating The Phenomena Of Geological Terms And Their Translation Problems In Linguistics
}

\author{
Rikhsieva Lola Azimjanovna \\ Senior Teacher, UzSWLU, The Department Of English Translation Theory And Practice, \\ Tashkent City, Uzbekistan
}

Copyright: Original content from this work may be used under the terms of the creative commons attributes 4.0 licence.

\section{ABSTRACT}

The terminology of a particular field of science or technology is highly specialized structure. At each historical stage in the development of geology, the number of lexical units of geological terminology is commensurate with the mass of acquired knowledge. With the growth of knowledge, the need for new terms increases, which is partially offset by borrowing terms from other areas of knowledge and to some extent satisfied by the formation of new terms. The article is about the term system of geology. It tries to describe the phenomena inherent in Geology and the problems of their their translation. Texts related to geological science are very difficult to study, and not only ordinary people experience difficulties in acquaintance with one of these texts, but also difficulties arise among specialists. Geological systems of terms are of great importance not only for our country, but also for the whole world. , since the development of the earth's crust is carried out in all corners of the globe.

\section{KEYWORDS}

Term system, geological terminology, raw materials, minerals, metallurgy, construction, physics

\section{INTRODUCTION}

The history of English geological science began in 1815, when the English geologist William Smith created a large - scale map that displayed the geological composition of a large regional Geological map of England and Wales. The map showed mountain strata identified by the fossils they contained. In 1822, by studying the Carboniferous and Cretaceous systems, a 
new scientific field was founded - stratigraphic systematics. The main divisions of the modern stratigraphic scale were officially adopted in 1881 in Bologna at the 2nd International geological Congress. A large percentage of the geological term system consists of borrowings.

This feature is inherent in almost all systems of terms. Borrowing from other languages is a natural procedure that forms terminology and language. This phenomenon contributes to the further internationalization of the language, which undoubtedly makes a huge contribution to the expansion of the use of terms by other language groups.

\section{MATERIALS AND METHODS}

The geological term system contains many concepts that describe the phenomena inherent in Geology: minerals, natural phenomena, equipment for geological research. The number of lexical units of geological terminology is commensurate with the mass of acquired knowledge at each historical stage in the development of geology. Therefore, with increasing knowledge, the need for new terms increases, which is partially compensated by borrowing terms from other areas of knowledge and to some extent satisfied by the formation of new terms.

In the XIX century, there was a huge leap in the study of Geology, respectively, along with science, terminology is developing. There were new phenomena in geological science that required new terms for designation. In 1841-43, the first Russian "Mining dictionary" was published in Russia, which includes 3,850 terms on mining, Geology, metallurgy, construction, physics, and chemistry. The last period of development of the geological system of terms falls at the end of the XIX century and up to the present day. This period is marked as a time of rapid technological progress, which implies a rapid development of geological terminology.
Now it is necessary to understand the concepts of "term" and "term system", find out their meaning, method of formation and function. The word "term" was derived from the Latin "terminus" - limit, border. This means that the term delimits something, pushes it into a framework. Terms are restrictive designations of an object or phenomenon in a particular area. They are part of the terminology and cannot exist without it. Also, terms differ from common words in that they are not related by context.

Within this system of concepts, the term should ideally be unambiguous, systematic, and stylistically neutral. Terms and words in a common language can overlap. They follow the rules of word formation, grammatical rules, and phonetic rules. Nowadays, science is trying to unify the system of terms, which should lead to simplification of its use, reducing the number of synonymous terms to avoid difficulties in understanding some units of the system. A term is a part of a language designed to nominate new phenomena in culture, science, or social life. And as part of the language, it must obey its rules. A term is a unit formed under the influence of external and internal factors, often chaotic and spontaneous. Performing a nominative function, the term helps to form a special base of elements-the term base.

This system of elements is irreplaceable in scientific activity. Thanks to it, we can easily find the name of a scientific phenomenon. The term database is especially useful if it is bilingual. Its use solves the difficulties that arise when working with specialized literature in a foreign language. The term, being a part of the term system, is subject to certain structural rules and logic of the system. Each part of it should correspond to its describe the phenomena inherent in Geology. The concept of "term system " can be said to have several 
forms, such as" system of terms","terminological system". They all have the same value. Thus, it can be argued that the term system is an ordered database of terms that is designed to systematize the terminology of a particular field of research.

The terminological geological system is a dynamic element of language learning. It changes over time. New terms appear, old ones are discarded, and the approach to creating such systems changes. Geological systems of terms are of great importance not only for our country, but also for the whole world, since the development of the earth's crust is carried out in all corners of the globe. Texts related to geological science are very difficult to study, and not only ordinary people have difficulty getting acquainted with one of these texts, but also among specialists there are difficulties.
The name of science is formed from a combination of two words of the ancient Greek language: "geo" - earth and "logos" - word. In other words, "Geology" is the science of the earth, it studies the structure of the earth's crust, the ways of formation of underground fossils. Often, when nominating new phenomena and objects, already known forms of words are used, which only slightly change due to factors of a particular industry. The mining and processing industries are of great importance for the economy of our country, as the raw materials industry is particularly developed in the world. Now the problem of good translation in such industries is particularly relevant. Therefore, companies are focused on finding a good translation specialist to work with this kind of documentation and specialized literature. For example, in English, you can find a lot of words that can't be translated correctly without context.

The examples of the terminology base is given in the Table 1.

\begin{tabular}{|c|c|c|c|c|c|}
\hline $\begin{array}{l}\text { Name of the } \\
\text { minerals } \\
\text { (English) }\end{array}$ & $\begin{array}{l}\text { Name of } \\
\text { minerals } \\
\text { (Uzbek) }\end{array}$ & $\begin{array}{c}\text { Procedures } \\
\text { (English } \\
\text { language) }\end{array}$ & $\begin{array}{l}\text { Proce } \\
\text { dures } \\
\text { (Uzbe } \\
\text { k) }\end{array}$ & $\begin{array}{l}\text { Equipen } \\
\mathrm{t} \\
\text { (English } \\
\text { languag } \\
\text { e) }\end{array}$ & $\begin{array}{c}\text { Equipment } \\
\text { (Uzbek } \\
\text { language) }\end{array}$ \\
\hline acicular & $\begin{array}{c}\text { igna } \\
\text { shaklidagi } \\
\text { kristall }\end{array}$ & accretion & $\begin{array}{l}\text { kristallni } \\
\text { yuvish }\end{array}$ & drilling rig & $\begin{array}{l}\text { burg'ulash } \\
\text { moslamasi }\end{array}$ \\
\hline $\begin{array}{c}\text { acicular iron } \\
\text { one }\end{array}$ & temir igna & Drilling & burg'ulash & vinyl flooring & $\begin{array}{c}\text { vinil } \\
\text { qoplama }\end{array}$ \\
\hline $\begin{array}{l}\text { acicular } \\
\text { mineral }\end{array}$ & $\begin{array}{l}\text { nayzali } \\
\text { mineral }\end{array}$ & hydration & namlantirish & pump & nasos \\
\hline
\end{tabular}




\begin{tabular}{|c|c|c|c|c|c|}
\hline $\begin{array}{c}\text { acicular } \\
\text { rutile }\end{array}$ & igna rutil & hydrolysis & gidroliz & drilling bit & $\begin{array}{c}\text { burg'ulash } \\
\text { bitigi }\end{array}$ \\
\hline
\end{tabular}

\section{DISCUSSION AND RESULTS}

The Russian linguist I. V. Arnold described the system as "an ordered and internally organized collection (set) of interconnected and interacting objects.

The elements of the system form an integral complex, are subordinated to the relations of hierarchy, can, in turn, be considered as subsystems and function in interaction with the external environment" (I. V. Arnold, "Lexicology of modern English" p.18, 2012).

The science that the term system belongs to forms its content and features (for example, geological science). Therefore, it is important learn a language at the lexical and semantic levels. There are a large number of definitions in linguistics now language systems. Most definitions boil down to the fact that the language is:

"A semiotic functional system serving to exchange information and its storage in human society and human consciousness "(G.O. Vinokur," On some phenomena of word formation in Russian technical terminology ", p. 56, 1939)," system of systems, inside which distinguish phonetic, morphological, lexical,

syntactic and other subsystems (Tatarinov V.A." History of Russian terminology").

The terminology of a particular field of science or technology is highly specialized structure. Such a system of terms characterized by limitations and focus on a certain field of knowledge. The classification of terminology is based on, before total, a sign of the number of components (term-forming elements), constituting the term combination. The core of any terminology is one-component terms (terms - words): integral (mathematics), inclination (linguistics), nuclinoid (chemistry). Based on one-word terms, more complex terminology is built: terminological phrases reflecting generic relations between the main and derivative names.

The term is always is a member of a certain terminology system. The meaning of a word is a term associates it primarily not with a separate subject, but with their class, next to, type. The core of the terminology is onecomponent terms, on the basis of which more complex terminology is built. Because the term is a word or phrase in a particular expression function a special concept, the same lexicosemantic processes occur in terminology as in the vocabulary of the general literary language.

Geological language is one of the style varieties natural language - scientific. This language belongs to the scientific style is determined by its specific terminology and certain type of syntactic structures. The specificity of the vocabulary of the scientific language is related with the fact that its main semantics is based on terms and words general literary and scientific language. General vocabulary words most often play the role of a connecting term between the words of scientific terminology.

This is due to the general function of the scientific language - conveying knowledge the most in a clear, economical and informative way. MG Berger noted the imperfection of the geological language: "In the current terminology of the most diverse areas of geological science is in dire need of a deep analysis of its state, development and 
improvement ". (M. G. Berger" Linguistic requirements for term ", p. 53-54, 1965) "Definitions of most geological concepts or not, or they are not strictly defined logically. Moreover this applies not only to complex, but relatively simple and often used terms "A.N. Kosygin. [("Kosygin Alexey Nikolaevich //Great Soviet Encyclopedia: in 30 volumes / ed. A.M. Prokhorov - 3rd ed. - M .: Soviet encyclopedia, 1973. - T. 13: Konda - Kuhn. - FROM. 282.)

The creation of a terminology base in the field of Geology can be of great benefit to individual industries, such as mining, oil production or precious metals, as well as to the entire geological industry. That is why the task of creating a complete, competent database is so important. To do this, linguistics specialists must conduct a thorough analysis of Uzbek and foreign language terminology, create a database based on it in two languages, structure it correctly, identify similarities and differences between the two terminological databases and adapt them for use specialistsgeologists.

\section{CONCLUSION}

English terminology in geological science was formed for the most part by borrowing words from the German language, since the first works on mining began to appear in Germans. Borrowings from German terminology can be observed in the following examples: stulmadit, miningsurveyor- surveyor, wornaugerauger, zink-zinc, soil-soil. The term molybdenum- molybdenum, was borrowed from the Latin language-molybdenum.

\section{REFERENCES}

1. G. O. Vinokur, on some phenomena of word formation in Russian technical terminology (1939)//Tatarinov V. A. History of Russian terminology. Classics of terminology: Essay and anthology, Moscow, 1994.

2. V. V. Vinogradov, on homonymy in the Russian lexicographic tradition// Selected works. Lexicology and lexicography, Moscow, 1977. 288 - 294.

3. A. A. Bogdasarova, "Comparative analysis of Russian and English languages", 1997

4. Alekseev M. N. Sofiano T. A. EnglishRussian geological dictionary,1997

5. "Dictionary of geological terms and concepts", Tomsk, 1992 - p. 60, 1995

83 S., 199685 p., compiled by: Prof. Parnachev V. P., prof. Vulcan I. A.,Prof. Tanzybaev M. G., prof. Rudoy A. N., eng. Kotelnikova I. V.

6. Glossary of Geology, USA, American geological Institute, 1997

7. Superanskaya A.V., Podolskaya N. V. Vasilyeva N. V. General terminology: questions of theory [Text] / A.V. Superanskaya, N. V.Podolskaya, N. V. Vasilyeva, Moscow: Nauka, 1989, 246 p.

8. Tikhonov A. N. Basic concepts of Russian word formation [Text] / A. N. Tikhonov // Word-forming dictionary of the Russian language: In 2 t. T. 1.M.: Rus. yaz., 1985. $856 \mathrm{p}$.

9. Geonaft Website http://www.geonaft.ru /

10. Lviv M. R. Dictionary-reference book on the methodology of the Russian language. M.,1997.

11. L. I. Barannikova, Introduction to linguistics, 2010

12. Alekseeva L. M. Problems of term and term formation:

13. A textbook on a special course. Perm, 1998.53

14. Big encyclopaedic dictionary (BES) Linguistics/GL. edited by V. N.Yartsevo. 2nd (reprint) edition of the Linguistic dictionary in 1990. - M.,2000. - 685 p.

Buyanova L. Yu. term Formation as an aspect of language//Actual problems of 
Philology in higher education and at school.

Tver, 1995.

15. GAK V. G. Language transformations. M., 1998. - $768 \mathrm{p}$.

16. AUBRY, M.-P., 2007a. Chronostratigraphic terminology: Building on principles. Stratigraphy, 4: 117-125..

17. AUBRY, M.-P., BERGGREN, W. A., VAN COUVERING, J. A. and STEININGER, F., 1999. Problems in chronostratigraphy: Stages, series, unit and boundary stratotypes, GSSPs, and tarnished Golden Spikes. Earth Science Reviews, 46: 99-148. 